\title{
Antibacterial, Antifungal, and Antioxidant Activity of Cleome coluteoides: An In Vitro Comparative Study Between Leaves, Stems, and Flowers
}

\section{Cleome coluteoides Boiss Antibakteriyel, Antifungal ve Antioksidan Aktiviteleri:Yaprak, Çiçek ve Kök Ekstrelerinin In Vitro Karşılaştırmalı Çalışması}

\author{
(D) Parastoo ZARGHAMI MOGHADDAM1, (D) Ameneh MOHAMMADI1, (D) Paiman ALESHEIKH¹, (D) Peyman FEYZI1, (D) Ali HAGHBIN1, \\ (D) Samaneh MOLLAZADEH ${ }^{1}$, (D) Zahra SABETI2, (D) Ailar NAKHLBAND1', (D) Jamal KASAIAN ${ }^{1 *}$ \\ ${ }^{1}$ North Khorasan University of Medical Sciences, Natural Products and Medicinal Plants Research Center, Bojnurd, Iran \\ 2Mashhad University of Medical Sciences School of Pharmacy, Department of Microbiology and Virology, Mashhad, Iran
}

\begin{abstract}
Objectives: Cleome coluteoides, which belongs to the Capparidaceae family, and has been used in folk medicine for a long time. Our research aims to measure the antioxidant, antibacterial, and antifungal activities of $C$. coluteoides.

Materials and Methods: Various solvents, such as ethyl acetate, methanol, and dichloromethane, were used to extract different plant parts. Antibacterial and antifungal activities were assayed by disk and well diffusion methods, and the antioxidant activity was screened by 2,2-diphenyl1-picrylhydrazyl (DPPH) and ferric reducing ability of plasma methods.

Results: Results showed that Gram-negative bacteria and fungus were resistant to various plant extracts. Against all Gram-positive bacteria tested, C. coluteoides' flower extract had the highest inhibition effects. Also, the most sensitive bacterium was Bacillus cereus, which had an 18-mm inhibition zone. Due to the solvent's physical and chemical properties, different $C$. coluteoides extracts exhibited various antioxidant activities in the antioxidant activity assay. To some extent, methanol extract of leaves showed the highest DPPH radical scavenging activity at various concentrations that ranged from 5 to $160 \mathrm{mg} \cdot \mathrm{mL}^{-1}$. The methanol extract of flower was observed to have the highest level of phenolics among all tested extracts.

Conclusion: This study demonstrates that different extracts from various $C$. coluteoides parts are different in their properties, therefore, a proper solvent should be used to extract maximum amounts of antioxidant and antibacterial components from a typical plant material.
\end{abstract}

Key words: Cleome coluteoides, antibacterial, antifungal, antioxidant

ÖZ

Amaç: Cleome coluteoides, Capparidaceae familyasına aittir ve uzun süredir geleneksel tıpta kullanılmaktadır. Çalışma C.coluteoides'in antioksidan, antibakteriyal ve antifungal aktivitesini ölçmeyi amaçlamıştır.

Gereç ve Yöntemler: Bitkinin farklı kısımları etil asetat, metanol ve diklorometan gibi çeşitli çözücüler ile ekstre edildi. Antibakteriyel ve antifungal aktiviteler disk ve kuyu difüzyon yöntemleriyle, antioksidan aktivite ise 2,2-difenil-1-pikrilhidrazil (DPPH) ve ferrik indirgeme kabiliyeti ile belirlendi. Bulgular: Sonuçlar, Gram-negatif bakteri ve mantarların yukarıda bahsi geçen çeşitli bitki ekstrelerine karşı dayanıklı olduğunu gösterdi. C. coluteoides'in çiçek ekstresi, test edilen Gram-pozitif bakterilerin tümüne karşı en yüksek inhibitör etkiye sahipti. Ayrıca, Bacillus cereus, 18-mm inhibitör zonuyla en hassas bakteridir. Antioksidan aktivite analizinde, farklı C. coluteoides ekstreleri, solvanların fiziksel ve kimyasal özelliklerinden dolayı çeşitli antioksidan aktiviteler göstermişlerdir. Bir şekilde, yaprakların metanol ekstresi, 5-160 mg. $\mathrm{mL}^{-1}$ arasında değişen konsantrasyonlarda en yüksek DPPH serbest radikal süpürücü aktivite göstermiștir. Test edilen ekstreler arasında çiçeklerin metanol ekstresinin en yüksek fenolik içeriğe sahip olduğu bulundu.

Sonuç: Bu çalışma, C. coluteoides' in çeşitli kısımlarının özelliklerinin farklı̈zelliklere sahip olduğunu göstermektedir, bu nedenle bir bitki materyalinin optimize edilmiş antioksidan ve antibakteriyel aktiviteleri için uygun bir çözücü bulmak hayati öneme sahiptir.

Anahtar kelimeler: Cleome coluteoides, antibakteriyel, antifungal, antioksidan

*Correspondence: kasaianj1@gmail.com, Phone: +09858-31513017 ORCID-ID: orcid.org/0000-0002-5661-5106

Received: 08.06.2019, Accepted: 24.10.2019

๑Turk J Pharm Sci, Published by Galenos Publishing House. 


\section{INTRODUCTION}

Free radicals are unstable and highly reactive atoms/groups with unpaired electrons, which can cause membrane damage, heart complications, aging, and cancer. To protect damages caused by free radicals, antioxidants can be used. The stability of drugs, foods, and nutrients and increase antiinflammatory, antiallergic, and anticancer potential of the human body can be efficiently improved by natural antioxidants. Plants with high phenolic contents, on the other hand, are a good source of powerful antioxidants. ${ }^{2}$ One of the most serious public health problems is microbial resistance to antibiotics, especially in developing countries where infectious diseases are a major cause of human mortality. ${ }^{3}$ Thus, there is great interest in finding new compounds derived from medicinal plants. Brought to light by recent studies, organic herbs contain secondary metabolites that make them good candidates for traditional or native remedies, especially as antimicrobial and antifungal agents. ${ }^{4}$ Recent investigations have proved that pathogenic microbes can be controlled via medicinal plants-based drugs. ${ }^{5}$ Accordingly, examining different medicinal plant extracts and constituents is essential for their antibacterial activity.

Cleome $\mathrm{L}$. belongs to Capparidaceae family, and is a large genus with 200 species worldwide. Because of its ethnomedicinal properties, including anthelmintic, carminative, anticonvulsant, antidiarrheal, antimicrobial, and wound-healing effects, this genus has been used in folk medicine for a long time. ${ }^{6}$ Some species in this genus, such as Cleome arabica L, Cleome viscosa Linn, Cleome droserifolia (Forssk.), Cleome enrichment, Cleome rutidosperma DC, Cleome gynandra L, possesses antipyretic and antidiarrheal properties, and have been used as traditional medicine in treatment of scabies, inflammation, rheumatic pains, blood problems, uterine complaints, malaria, counteract diabetic hyperglycemia, treat paralysis, anthelmintic problems, epilepsy, convulsions, spasm, pain, and skin disease. ${ }^{7-11}$ Different parts of Cleome genus like leaves, roots, and seeds are used as stimulant, antiscorbutic, anthelmintic, rubefacient, vesicant, and carminative factors according to the mentioned traditional applications.12 Phytochemical screening studies of the Cleome genus found phenolic compounds, alkaloids, terpenoids, flavonoids, fatty acids, coumarino-lignan, and rich source of nutrients, especially vitamins $A$ and $C$, protein, gallotannins, saponins, iridoid, hexacosanol, and kaempferol.,13-17 Therefore, a promising approach is to find natural antibacterial, antifungal, and antioxidant agents with similar therapeutic effect that is safer and healthier..$^{18}$ To date, the chemical composition and pharmacological effects of various species of Cleome have been reported. However, to our knowledge, Cleome coluteoides' chemical components and extracts-related activities have not been shown. The focus of this study is on the antioxidant, antibacterial, and antifungal activities of various extracts of $C$. coluteoides.

\section{MATERIALS AND METHODS}

Folin-Ciocalteau reagent (F9252, Sigma-Aldrich), gallic acid (91215, Fluka), aluminum chloride (563919, anhydrous powder,
99.999\%, Sigma-Aldrich), 2,2-diphenyl-1-picrylhydrazyl (257621, Sigma-Aldrich), 2,4,6-tripyridyl-s-triazine (T1253 for spectrophotometric, $\geq 98 \%$, Sigma), butylated hydroxy toluene (BHT) (W218405 $\leq 99$, Sigma-Aldrich), $\mathrm{Na}_{2} \mathrm{CO}_{3}$ (451614, anhydrous powder, 99.999\%, Sigma-Aldrich), $\mathrm{FeSO}_{4} \cdot 7 \mathrm{H}_{2} \mathrm{O}$ (21542, $\geq 99.0 \%$, Sigma-Aldrich) were used in this study.

In June 2017, the stems, flowers, and leaves of $C$. coluteoides were collected from the Roein region of the North Khorasan Province of Iran. The voucher specimen (MP.1247) was authenticated by botanist and it has been deposited at the Herbarium of Natural Products and Medicinal Plants Research Center in North Khorasan University of Medical Sciences. From Pasteur Institute of Iran, bacterial and fungal strains were procured.

\section{Extracts preparation}

Various solvents, such as ethyl acetate, methanol, and dichloromethane, were used to separately extract powdered stems, flowers, and leaves of $C$. coluteoides by maceration method for $24 \mathrm{~h}$ at room temperature. To yield crude extracts, they were filtered through a paper filter and the solvent was evaporated under a vacuum at $45^{\circ} \mathrm{C}$.

\section{Microorganisms}

Escherichia coli (ATCC 8739), Bacillus cereus (PTCC 1247), and Staphylococcus aureus (ATCC 6538) were the microorganisms used for antimicrobial activities screening, whereas Fusarium solani (PTCC 5284) and Candida albicans (ATCC 10231) were applied for antifungal tests. Disk and well diffusion methods (CLSI 2012 standard) were used in this study for the antimicrobial activity assay.

\section{Well diffusion method}

Punched into the agar plates were 6-mm diameter wells with Mueller-Hinton agar (MHA) for bacterial and Soybean Casein Agar [(SCA) or Tryptic Soy Agar)] for fungal strains. On the plates' surface, a density of $1.5 \times 10^{8}$ microorganism cells had been spread. Next, added into the wells were $50 \mu \mathrm{L}$ plant extracts $\left(100 \mathrm{mg} \cdot \mathrm{mL}^{-1}\right)$. Incubation lengths were $16-20 \mathrm{~h}$ at $37^{\circ} \mathrm{C}$ for bacteria and $36-48 \mathrm{~h}$ at $32^{\circ} \mathrm{C}$ for fungi; inhibition zones $(\mathrm{mm})$ were then measured. ${ }^{19}$

\section{Disk-diffusion method}

The discs (6 mm diameter) contained plant extracts (100 $\left.\mathrm{mg} \cdot \mathrm{mL}^{-1}\right)$ were placed on the plates containing MHA for bacterial and SCA for fungal strains with $1.5 \times 10^{8}$ microorganism cells. Incubation lengths for bacteria and fungi were $16-20 \mathrm{~h}$ at $37^{\circ} \mathrm{C}$ and $36-48 \mathrm{~h}$ at $32^{\circ} \mathrm{C}$, respectively. By measuring the zone of inhibition zones surrounding the disks, antimicrobial activity was evaluated. Gentamycin and nystatin were used as a positive control and dimethyl sulfoxide as a negative control. ${ }^{20}$

\section{Antioxidant activity evaluation}

Free radical scavenging activity assay

1,1-diphenyl-2-picrylhydrazyl (DPPH) was used to assess the free radical scavenging activity. To do so, in a 96-well microplate, $100 \mu \mathrm{L}$ of each extract $(5-160 \mathrm{mg} / \mathrm{mL})$ was incubated with $200 \mu \mathrm{L}$ 
DPPH $(300 \mu \mathrm{M})$ at $37^{\circ} \mathrm{C}$ for $30 \mathrm{~min}$. After that, an enzyme-linked immunosorbent assay (ELISA) microplate reader (BioTek) was used to measure absorption at $490 \mathrm{~nm}$. $\mathrm{MeOH}$ and $\mathrm{BHT}$ were used as blank and positive controls, respectively. Free radical inhibition of DPPH was calculated as follows:

$\%$ inhibition: $\left(A_{\text {blank }}-A_{\text {sample }} / A_{\text {blank }}\right) \times 100$,

where $A_{\text {blank }}$ is the absorbance of the blank group and $A_{\text {sample }}$ is the absorbance of each extract. ${ }^{21}$

\section{Ferric reducing antioxidant power assay}

As a standard, ferrous sulfate $\left(10-100 \mathrm{mM} \mathrm{FeSO}_{4} \cdot 7 \mathrm{H}_{2} \mathrm{O}\right)$ was used. The ferric reducing antioxidant power (FRAP) reagent ( $3 \mathrm{~mL}$ ) was added $100 \mu \mathrm{L}$ of each extract $(50 \mathrm{mg} / \mathrm{mL}$ ), and was incubated in a water bath for $10 \mathrm{~min}$ at $37^{\circ} \mathrm{C}$. By using the ELISA microplate reader, the absorbance was measured at $600 \mathrm{~nm}$ after incubation. All tests were performed in triplicates. The results were presented as means \pm standard deviation (SD), and FRAP values were expressed as mmol Fe (2) per gram of extract. $^{22}$

\section{Determination of total phenolic content}

In 96-well plates, $10 \mu \mathrm{L}$ of each extract was added to $100 \mu \mathrm{L}$ of Folin-Ciocalteu's phenol reagent $(0.2 \mathrm{~N})$. After $3 \mathrm{~min}$, added to the mixture was $90 \mu \mathrm{L}$ of saturated sodium carbonate solution and was incubated at room temperature for $1 \mathrm{~h}$. The samples were measured at $630 \mathrm{~nm}$. Gallic acid (concentration range 3.25 to $500 \mathrm{mg} / \mathrm{mL}^{-1}$ ) was used to calculate the total phenolic content by standard curve. Results were expressed as microgram gallic acid equivalent (GAE) per milligram dry weight (DW) ( $\mu g$ GAE/ mg DW). ${ }^{21,22}$

\section{Statistical analysis}

For each experimental point, data were expressed as mean \pm SD for at least three independent determinations in triplicate. GraphPad Prism version 5.01 software was used to calculate the $\mathrm{IC}_{50}$ values in $\mathrm{DPPH}$ test.

\section{RESULTS}

Different extracts from various parts of $C$. coluteoides, as expected, represented different extractable yield amounts. Extracts are expressed as follows: Dichloromethane extract of leaves (DEL); methanol extract of leaves (MEL); ethyl acetate extract of leaves (EEL); dichloromethane extract of flower (DEF); methanol extract of flower (MEF); ethyl acetate extract of flower (EEF); dichloromethane extract of stem (DES); methanol extract of stem (MES); and ethyl acetate extract of stem (EES). MEF obtained the highest yield (9.63\%) and the lowest ones were from DES and EES. Altogether, to get more yields from various parts of the plant, the methanol solvent system could be more efficient (Figure 1). Disc/well diffusion methods were used to test the antibacterial and antifungal activities of dried extracts (ethyl acetate, methanol, and dichloromethane extracts) of stems, flowers, and leaves were tested for antibacterial and antifungal activities, and their results are shown in Table 1 . In both methods, the diameter of inhibitory zones for Gram-negative bacteria and fungus was
$6.0 \mathrm{~mm}$, and all microorganisms were resistant to various plant extracts. Therefore, well and disk-diffusion method results were similar. Against all the tested microorganisms, flower extract of $C$. coluteoides had the highest inhibition effects; however, its activity was markedly lower than gentamicin in bacteria. In the disk-diffusion method, $B$. cereus was the more sensitive bacteria with an inhibition zone of $18 \mathrm{~mm}$.

Table 2 presents the free radical scavenging activities of various extracts. It should be mentioned that a lower $\mathrm{IC}_{50}$ value indicates a higher antioxidant activity. Tests by DPPH radical scavenging activity showed that MEL exhibited remarkable antioxidant activities $(19.54 \pm 0.21 \mathrm{mg} / \mathrm{mL})$. All the plant parts' $I_{50}$ were higher than standard BHT, which was $0.15 \mathrm{mg} / \mathrm{mL}$. In Figure 2, the test samples' DPPH radical scavenging activity rapidly increased from 5 to $160 \mathrm{mg} / \mathrm{mL}$ in a dose-dependent manner. Findings indicated that dichloromethane extracts possessed the lowest antioxidant activity. Table 3 displays the total phenolic compound contents, which are expressed in $\mathrm{mg}$ EAG/g. Total phenolic compounds extracted from the samples significantly varied from each other. Methanol extracts showed higher phenolic contents than the others, followed by ethyl acetate and dichloromethane extracts.

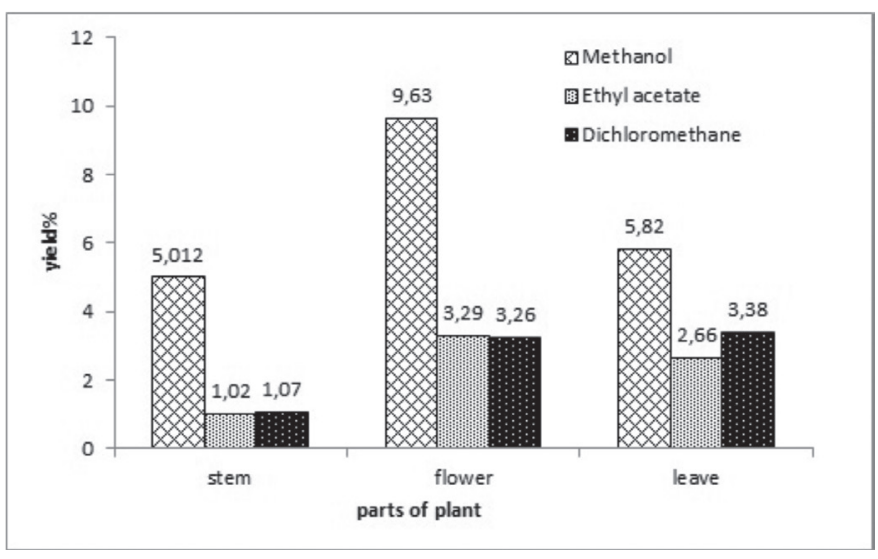

Figure 1. Extraction yields of different extracts from various parts of Cleome coluteoides

\section{DISCUSSION}

By extracting different parts of $C$. coluteoides, including leaves, flowers, and stems, with various types of solvent (methanol, dichloromethane, and ethyl acetate), plant parts were screened for antioxidant and antibacterial activities. Variation in the extract yields of the plant may be due to the various chemical natures of the compounds available in the leaves, barks and seeds may be the cause in the extract yield variation of the plant; polarity, solubility, concentration, $\mathrm{pH}$, temperature, and nature of the extraction solvents also affects the extraction yields. ${ }^{23}$ Hence, for the extraction of maximum amounts of potent antioxidant components from typical plant materials, a proper solvent system must be used. ${ }^{24}$ On the one hand, secondary metabolites are produced by medicinal plants, which are responsible for their therapeutic properties. Moreover, environmental factors like geographical locations and plant 
Table 1. Antifungal and antibacterial activities of dried extracts of $C$. coluteoides in disk and well diffusion method

\begin{tabular}{|c|c|c|c|c|c|c|c|}
\hline \multirow{3}{*}{ Sample } & \multicolumn{7}{|c|}{ Microorganism $^{a}$} \\
\hline & \multicolumn{2}{|c|}{ Bacillus cereus } & \multicolumn{2}{|c|}{ Staphylococcus aureus } & \multirow{2}{*}{$\begin{array}{l}\text { Escherichia coli } \\
\text { Disc and well }\end{array}$} & \multirow{2}{*}{$\begin{array}{l}\text { Candida albicans } \\
\text { Disc and well }\end{array}$} & \multirow{2}{*}{$\begin{array}{l}\text { Fusarium solan } \\
\text { Disc and well }\end{array}$} \\
\hline & Disc & Well & Disc & Well & & & \\
\hline MEF & $10.0 \pm 0.14$ & $10.0 \pm 0.28$ & $10.3 \pm 0.74$ & $11.3 \pm 0.37$ & - & - & - \\
\hline MEL & $14.3 \pm 0.24$ & $10.0 \pm 0.47$ & $12.0 \pm 0.52$ & $6.0 \pm 0.35$ & - & - & - \\
\hline EEL & $15.3 \pm 0.43$ & $11.0 \pm 0.38$ & $11.3 \pm 0.14$ & $11.6 \pm 0.26$ & - & - & - \\
\hline DEF & $15.0 \pm 0.16$ & $11.6 \pm 0.37$ & $6.0 \pm 0.21$ & $6.0 \pm 0.14$ & - & - & - \\
\hline DEL & $16.3 \pm 0.35$ & $11.3 \pm 0.41$ & $6.0 \pm 0.16$ & $10.0 \pm 0.12$ & - & - & - \\
\hline Gentamycin & $30.3 \pm 0.19$ & $32.3 \pm 1.15$ & $31.3 \pm 0.21$ & $40.0 \pm 0.23$ & $29.6 \pm 0.15$ & - & - \\
\hline
\end{tabular}

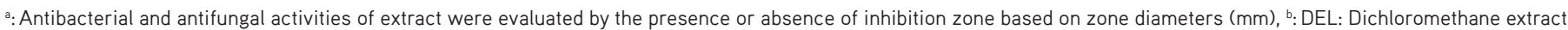

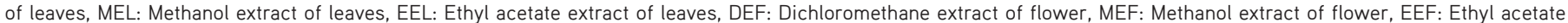
extract of flower, DES: Dichloromethane extract of stem, MES: Methanol extract of stem, EES: Ethyl acetate extract of stem, ${ }^{c}$ : Non-effective
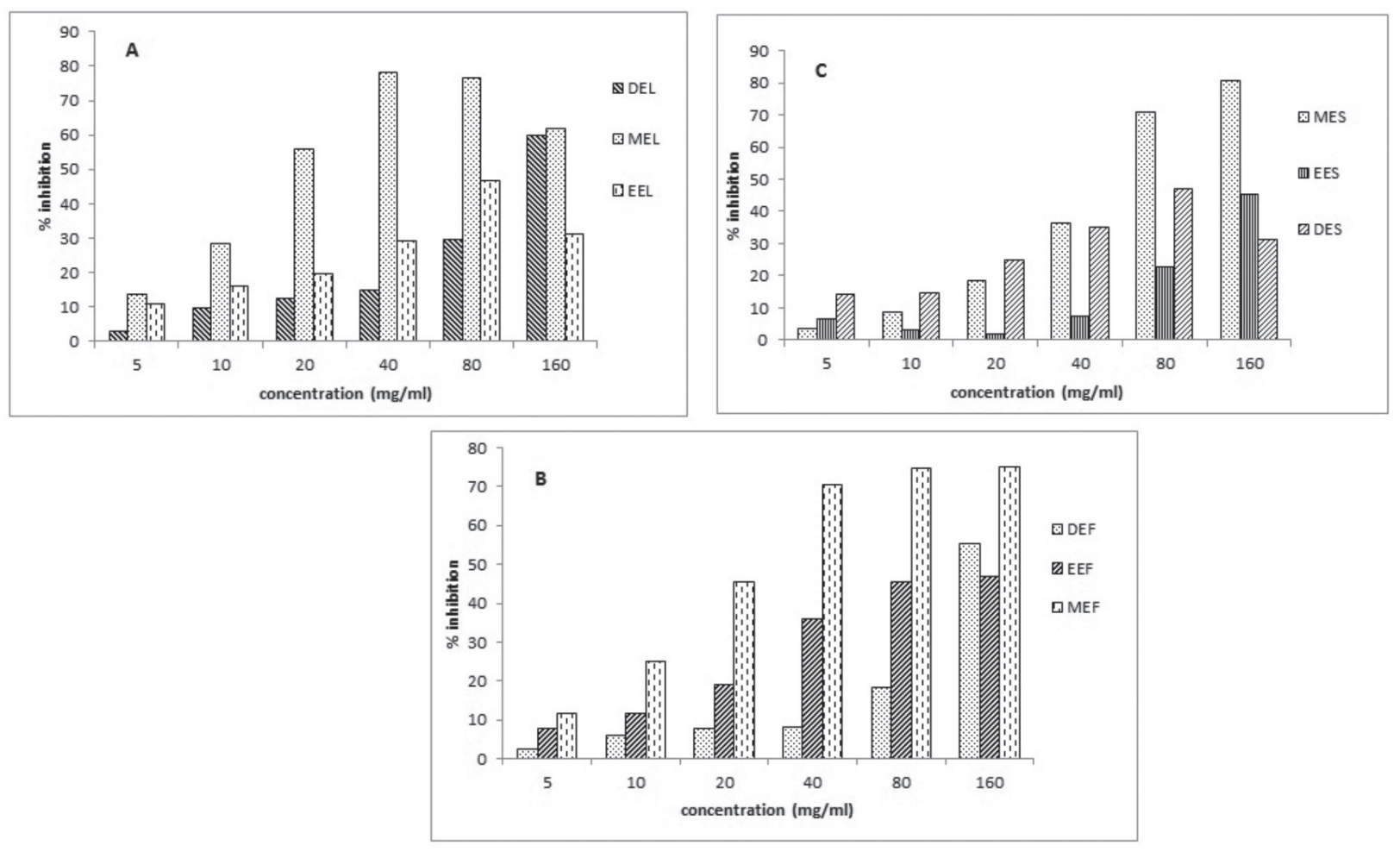

Figure 2. Radical scavenging activities of various extracts from different parts of Cleome coluteoides. (A) Leaves parts: DEL, dichloromethane extract; MEL, methanol extract; EEL, ethyl acetate extract. (B) flower parts: DEF, dichloromethane extract; MEF, methanol extract; EEF, ethyl acetate. (C) stem parts: DES, dichloromethane extract; MES, methanol extract; EES, ethyl acetate extract

origin affect the quality and quantity of these molecules and, conversely, their activities. ${ }^{25} \mathrm{C}$. coluteoides extracts were found to be inactive against tested bacterial and fungal strains in the present study. In return, Gram-positive bacterial strains dedicated better resistance to the extracts. Antimicrobial functions of medicinal plants are reported from several parts of the world. Today, the World Health Organization has approved the use of herbs or their active ingredients in the traditional way. ${ }^{26}$ As evidenced, methanol extract of $C$. viscosa exhibited the highest and significant antibacterial activity against seven bacterial strains. ${ }^{27}$ Subsequently, ethanolic extract of Cleome ciliata had inhibitory effects against $S$. aureus and Pseudomonas aeruginosa; the tannin fraction was active only against $S$. aureus. ${ }^{28}$ Antimicrobial test of $C$. viscosa's methanolic extract displayed moderate sensitivity to the Gram-positive and Gram-negative bacteria. Shigella sonnie was recorded to 
Table 2. Free radical scavenging activity and FRAP of different extracts from various parts of Cleome coluteoides

\begin{tabular}{lll} 
Sample & $\begin{array}{l}\text { FRAP (mmol } \\
F^{2}+/ g \text { extract) }\end{array}$ & $D^{D P P H ~ I C}(\mathrm{mg} / \mathrm{mL})$ \\
\hline MES $^{b}$ & $-c$ & $49.35 \pm 0.25$ \\
\hline MEF & $68.24 \pm 0.12$ & $24.02 \pm 2.02$ \\
\hline MEL & $90.98 \pm 0.12$ & $19.54 \pm 2.41$ \\
\hline EES & $59.44 \pm 0.18$ & $58.45 \pm 3.48$ \\
\hline EEF & $81.03 \pm 0.19$ & $157.25 \pm 1.49$ \\
\hline EEL & - & $159.33 \pm 1.64$ \\
\hline DES & $61.68 \pm 0.45$ & $99.05 \pm 5.17$ \\
\hline DEF & - & $424.02 \pm 0.25$ \\
\hline DEL & - & $169.90 \pm 2.66$ \\
\hline BHT & $14.32 \pm 0.58$ & $0.40 \pm 0.03$ \\
\hline
\end{tabular}

a: Data are expressed as mean \pm standard deviation, $(n=3)$, b: DEL: Dichloromethane extract of leaves, MEL: Methanol extract of leaves, EEL: Ethyl acetate extract of leaves, DEF: Dichloromethane extract of flower, MEF: Methanol extract of flower, EEF: Ethyl acetate extract of flower, DES: Dichloromethane extract of stem, MES: Methanol extract of stem, EES: Ethyl acetate extract of stem, ${ }^{c}$ : Non-effective, ${ }^{d}$ : Positive control, FRAP: Ferric reducing antioxidant power, BHT: Butylated hydroxy toluene, DPPH: 1,1-diphenyl-2-picrylhydrazyl

Table 3. Total polyphenolics contents of different extracts from various parts of Cleome coluteoides

\begin{tabular}{ll} 
Sample & Total polyphenols (mg GAE/g extract) \\
\hline MES & $14.81 \pm 0.15$ \\
\hline MEF & $24.58 \pm 0.35$ \\
\hline MEL & $23.27 \pm 0.14$ \\
\hline EES & $14.17 \pm 0.72$ \\
\hline EEF & $18.97 \pm 0.61$ \\
\hline EEL & $17.58 \pm 0.89$ \\
\hline DES & $5.24 \pm 0.57$ \\
\hline DEF & $15.87 \pm 0.45$ \\
\hline DEL & $5.66 \pm 0.36$ \\
\hline
\end{tabular}

${ }^{a}$ : Data are expressed as mean \pm standard deviation, $(n=3)$, DEL: Dichloromethane extract of leaves, MEL: Methanol extract of leaves, EEL: Ethyl acetate extract of leaves, DEF: Dichloromethane extract of flower, MEF: Methanol extract of flower, EEF: Ethyl acetate extract of flower, DES: Dichloromethane extract of stem, MES: Methanol extract of stem, EES: Ethyl acetate extract of stem, GAE: Gallic acid equivalent

have the highest inhibition zone $(16.34 \mathrm{~mm}) .{ }^{15} \mathrm{C}$. viscosa's crude extracts presented antibacterial potency against $P$. aeruginosa. ${ }^{5}$ Alkaloids and tannins were reported by other researchers to be present in C. viscosa, and are associated with antibacterial activity. ${ }^{5}$

$\mathrm{DPPH}$ and FRAP tests were the two methods used to evaluate the extracts' antioxidant activity. The antioxidants' potential to naturalize free radicals through reduction mechanisms are assessed by DPPH, which discolorates stable free radical $\mathrm{DPPH}$ of violet color to yellow. ${ }^{29} \mathrm{DPPH}$ scavengers is well known to have a wide range of biological functions such as lipid peroxidation inhibitory action and radioprotective. ${ }^{30}$ There is a line of evidence that show that plants' antioxidant and pharmacological properties are usually associated with the presence of phenolic compounds and as electron donor agents. ${ }^{31}$ In this study, a flower extracts' strong antioxidant activity is probably due to its phenolic contents. ${ }^{21}$ Similarly, C. gynandra's butanol fractions demonstrated remarkable anti-FRAP, -ABTS, and -DPPH activities. Moreover, C. gynandra's best phenolic content was obtained with $n$-butanol fraction. ${ }^{16}$ Soluble and stable iron complex, which can easily be excreted from the body, can be formed by phenolic and antioxidant compounds. ${ }^{32}$ Table 2 summarizes the extracts' ferrous chelating activities (known as an important antioxidant mechanism). According to the results, methanol extract had greater chelating action because of its higher phenol contents. As indicated in Table 3, the total phenolic contents of various $C$. coluteoides extracts ranged from $5.24 \pm 0.57$ to $24.58 \pm 0.35 \mathrm{mg} \mathrm{GAE} / 100 \mathrm{~g} \mathrm{DW}$, and the highest content was found in MEF (24.58 $\pm 0.35 \mathrm{~g} \mathrm{GAE} / \mathrm{g}$ DW). Furthermore, phenolic compounds were found in the following order: $\mathrm{MEF}>\mathrm{MEL}>\mathrm{EEF}>\mathrm{EEL}>\mathrm{DEF}>\mathrm{MES}>\mathrm{EES}>\mathrm{DEL}>\mathrm{DES}$. Collectively, the phenolic contents in each sample were in agreement with the findings of DPPH. In keeping with our results, plant phenolics act as reducing agents and antioxidants through their hydroxyl groups' hydrogen-donating property. ${ }^{33}$ Hence, antioxidant activity observed in this study could be explained by polyphenol contents. Thus, it can be concluded that the best solvent for $C$. coluteoides' antioxidant activity extraction was the methanol solvent. Our phenolic results of different plant parts reported greater amounts phenolics in the leaves than in the stem parts, which is in agreement with previous investigations. ${ }^{34}$ A larger amount of phenolic and flavonoid in plant leaves might be the result of photosynthesis in this section. ${ }^{35}$ Consistently, the highest amounts of total phenols in stem extracts of C. gynandra L. are determined in its aqueous extract. ${ }^{36}$ The varied scavenging activity in different plant parts could be attributed to the presence of bioactive compounds such as phenolics, flavonoids, and tannins. ${ }^{37}$ Previously, a strong correlation was observed between a plant extracts' radical scavenging power and total phenolic and flavonoid content. ${ }^{24}$ The present results provided evidence that most extracts with high phenolic content exhibited greater potency to scavenge free radicals. Nevertheless, some extracts with less phenolic amounts depicted appreciable activity, which suggests that the presence of other secondary metabolites (carotenoids, volatile oils, and vitamins) may also contribute to the scavenging capacity. ${ }^{38}$ Accordingly, in the current study MES had fewer phenolic amount than flowers, however, it exhibited greater antioxidant activity. ${ }^{39,40}$ In general, our antioxidant and antibacterial activity results are consistent with other Cleome species-related studies mentioned earlier. ${ }^{16}$

\section{CONCLUSION}

This study demonstrates that different extracts from various parts of $C$. coluteoides have different antioxidant and antimicrobial effects. As indicated in the results, MEL possessed the highest antioxidant properties and EEF had the highest antimicrobial activities, which are probably correlated with total phenolics. 
To characterize the antioxidant and antibacterial agents, phytochemical analysis on $C$. coluteoides' phytochemical should be conducted. This work demonstrates that extracting various parts of the plants with different solvents have variable antioxidant and antibacterial activities. To our knowledge, the antioxidant and antibacterial value of $C$. coluteoides were first revealed in this report.

\section{ACKNOWLEDGMENTS}

This study was financially supported by North Khorasan University of Medical Sciences, Bojnurd, Iran.

Conflicts of interest: No conflict of interest was declared by the authors. The authors alone are responsible for the content and writing of the paper.

\section{REFERENCES}

1. Venkatesh B, Dorai A. Antibacterial and antioxidant potential of white and pink nelumbo nucifera gaertn flowers. International Conference on Bioscience, Biochemistry and Bioinformatics. 2011;5:213-217.

2. Akyuz E, Şahin H, Islamoglu F, Kolayli S, Sandra P. Evaluation of phenolic compounds in tilia rubra subsp. caucasica by HPLC-UV and HPLC-UV-MS/MS. Int J Food Prop. 2014;17:331-343.

3. da Silva AP, Nascimento da Silva LC, Martins da Fonseca CS, de Araújo JM, Correia MT, Cavalcanti Mda S, Lima VL. Antimicrobial activity and phytochemical analysis of organic extracts from Cleome spinosa jaqc. Front Microbiol. 2016;7:1-10.

4. Oussalah M, Caillet S, Saucier L, Lacroix M. Inhibitory effects of selected plant essential oils on the growth of four pathogenic bacteria: E. coli O157:H7, Salmonella Typhimurium, Staphylococcus aureus and Listeria monocytogenes. Food Control. 2007;18:414-420.

5. Donkor AM, Gumah Bugri KM, Akugbire Atindaana E. Evaluation of Antibacterial Potentiation of Crude Extracts of Phyllanthus amarus, Tamarindus indica and Cleome viscosa and Their Formulation. Int J Plant Res. 2014:4:23-28.

6. Muhaidat R, Al-Qudah MA, Samir O, Jacob JH, Hussein E, Al-Tarawneh IN, Bsoul E, Abu Orabi ST. Phytochemical investigation and in vitro antibacterial activity of essential oils from Cleome droserifolia (Forssk.) Delile and C. trinervia Fresen. (Cleomaceae). S Afr J Bot. 2015;99:21-28.

7. Ladhari A, Omezzine F, DellaGreca M, Zarrelli A, Zuppolini S, Haouala R. Phytotoxic activity of Cleome arabica $L$. and its principal discovered active compounds. S Afr J Bot. 2013;88:341-351.

8. Motaal AA, Ezzat SM, Haddad PS. Determination of bioactive markers in Cleome droserifolia using cell-based bioassays for antidiabetic activity and isolation of two novel active compounds. Phytomedicine. 2011;19:38-41.

9. Shanmuganathan T, Karthikeyan AVP. Free radical scavenging activity of aqueous and ethanolic extracts of wild and L-arginine treated Cleome gynandra L. Int J Pharm Sci Res. 2014;5:346-349.

10. Parimaladevi B, Boominathan R, Mandal SC. Studies on analgesic activity of Cleome viscosa in mice. Fitoterapia. 2003;74:262-266.

11. Ding HY, Wu PS, Wu MJ. Cleome rutidosperma and Euphorbia thymifolia Suppress Inflammatory Response via Upregulation of Phase II Enzymes and Modulation of NF-KB and JNK Activation in LPS-Stimulated BV2 Microglia. Int J Mol Sci. 2016;17:1420.
12. Bose A, Mondal S, Gupta JK, Ghosh T, Si S, Debbhuti D. A study on antimicrobial activity of Cleome rutidosperma DC. Journal of Natural Remedies. 2007;7:132-134.

13. Abdel-Monem AR. A new alkaloid and a new diterpene from Cleome paradoxa B.Br. (Cleomaceae). Nat Prod Res. 2012;26:264-269.

14. Jordheim M, Andersen $\emptyset \mathrm{M}$, Nozzolillo C, Amiguet VT. Acylated anthocyanins in inflorescence of spider flower (Cleome hassleriana). Phytochemistry. 2009;70:740-745.

15. Bose U, Bala V, Nath Ghosh T, Gunasekaran K, Ayedur Rahman A. Antinociceptive, cytotoxic and antibacterial activities of Cleome viscosa leaves. Rev Bras Farmacogn. 2011;21:165-169.

16. Meda NTR, Bangou MJ, Bakasso S, Millogo-Rasolodimby J, Nacoulma OG. Antioxidant activity of phenolic and flavonoid fractions of Cleome gynandra and Maerua angolensis of Burkina Faso. J Appl Pharm Sci. 2013;3:36-42.

17. Singh H, Mishra A, Kumar Mishra A. Cleome viscosa Linn (Capparaceae): A Review. Pharmacogn J. 2015;7:326-329.

18. Sridhar KR, Rajeev B. Lotus - A potential nutraceutical source. J Agri Tech. 2007;3:143-155.

19. Baskaran C, Ratha bai V, Velu S, Kumaran K. The efficacy of Carica papaya leaf extract on some bacterial and a fungal strain by well diffusion method. Asian Pac J Trop Dis. 2012;2:658-662.

20. Kamali M, Khosroyar S, Mohammadi A. Antibacterial activity of various extracts from Dracocephalum kotschyi against food pathogenic microorganisms. Int J PharmTech Res. 2015;8:158-163.

21. Kamali H, Ahmadzadeh Sani T, Mohammadi A, Alesheikh P, Khodaverdi E, Hadizadeh F. A comparison between pressurized hot water and pressurized liquid extraction for optimizing phenolic and antioxidants capacity of the wooden layer between of walnut seed. J Supercrit Fluid. 2018;133:535-541.

22. Eslami A, Roghani K, Mohammadi A. In vitro antioxidant potential of polygonum convolvulus extracts. Plant Archives. 2017;17:267-270.

23. Roselló-Soto E, Martí-Quijal FJ, Cilla A, Munekata PES, Lorenzo JM, Remize F, Barba FJ. Influence of Temperature, Solvent and $\mathrm{pH}$ on the Selective Extraction of Phenolic Compounds from Tiger Nuts by-Products: Triple-TOF-LC-MS-MS Characterization. Molecules. 2019;24:797-810.

24. Namvar K, Mohammadi A, Ataei Salehi E, Feyzi P. Evaluation of Solvent Effect (Methanol: Water Mixture) on the Phenolic Content and Antioxidant Activities of Stachys turcomanica Trautv. J Pharm Sci. 2017;23:244-248.

25. Ullah N, Khurram M, Usman Amin M, Khan TA, Umar Khayyam S, Khan FA, Najeeb U, Ullah S. Impact of geographical locations on Mentha spicata antibacterial activities. J Med Plants Res. 2012;6:1201-1206.

26. Bhalodia NR, Shukla VJ. Antibacterial and antifungal activities from leaf extracts of Cassia fistula l.: An ethnomedicinal plant. J Adv Pharm Technol Res. 2011;2:104-109.

27. Saradha JK, Rao BS. 2010. In vitro antibacterial activity of Cleo me viscosa Linn. Int J Pharm Sci. 2011;1:71-78.

28. Umerie SC, Okorie NH, Ezea SC, Okpalaononuju AN. Antibacterial screening and phytochemical analysis of Cleome ciliate (capparidaceae) leaves. Int J Curr Res Rev. 2012;4:1-10.

29. Brand-Williams W, Cuvelier ME, Berset C. Use of a free-radical method to evaluate antioxidant activity. Food Sci Technol. 1995;28:25-30. 
30. Rahman MM, Islam MB, Biswas M, Khurshid Alam AHM. In vitro antioxidant and free radical scavenging activity of different parts of Tabebuia pallida growing in Bangladesh. BMC Res Notes. 2015;8:621630.

31. Gülçin I. Antioxidant activity of food constituents: an overview. Arch Toxicol. 2012;86:345-391.

32. Faa G, Crisponi G. Iron chelating agents in clinical practice. Coord Chem Rev. 1999;184:291-310.

33. Aberoumand A, Deokule SS. Comparison of phenolic compounds of some edible plants of Iran and India. Pakistan J Nut. 2008;7:582-585.

34. Karimi E, Jaafar HZE, Ahmad S. Phenolics and flavonoids profiling and antioxidant activity of three varieties of Malaysian indigenous medicinal herb Labisia pumila Benth. J Med Plant Res. 2011;5:1200-1206.

35. Silva EM, Souza JNS, Rogez H, Rees JF, Larondella Y. Antioxidant activities and polyphenolic contents of fifteen selected plant species from the Amazonian region. Food Chem. 2006;101:1012-1018.
36. Essou JIL, Zanklan AS, Adomou AC, Assogba F. Studies on Phytochemistry and Antioxidant Potential of Cleome Gynandra L. (Capparidaceae) Collected from Contrasted Agro-Ecological Zones in Benin. Eur J Sci Res. 2017;147:251-274.

37. Ghimire BK, Seong ES, Kim EH, Ghimeray AK, Yu CY, Ghimire BK, Chung IM. A comparative evaluation of the antioxidant activity of some medicinal plants popularly used in Nepal. J Med Plants Res. 2011;5:18841891.

38. Yingming $P$, Ying L, Hengshan W, Min L. Antioxidant activities of several Chinese medicinal herbs. Food Chem. 2004;88:347-350.

39. Odabasoglu F, Aslan A, Cakir A, Suleyman H, Karagoz Y, Bayir Y, Halici M. Antioxidant activity, reducing power and total phenolic content of some lichen species. Fitoterapia. 2005;76:216-219.

40. Moghaddam PZ, Mohammadi A, Feyzi P, Alesheikh P. In vitro antioxidant and antibacterial activity of various extracts from exocarps and endocarps of walnut. Pak J Pharm Sci. 2017;30:1725-1731. 